\title{
O emoční hlubinné dimenzi pedagogických situací ve škole: Po stopách snah o zařazení psychologicky hlubinně orientovaného sebepoznávání do vzdělávání učitelů
}

\author{
Ehrenhard Skiera
}

\begin{abstract}
Abstrakt: Ačkoli téměr každý pedagog a pedagožka ví, že vzdělávaci prostor je plný hlubokých emocí, které utváreji interakce, nepodarilo se doposud poskytnout odpovidajici pozornost souvisejicim otázkám ve vzděláváni učitelu. Existuji však př́stupy, které se snaži integrovat hlubinnè-psychologické aspekty do „běžného “vzdèláváni učitelì a učitelek pro predškolni, základni a středni vzděláváni. Zásadni význam zde maji koncepty, které presahuji teoretické informace, práci s príslušnými texty na prédnáškách a seminárích a integruji v kurikulárni a institucionálni rovině problematiku sebeuvědomèni a „reflexivního sebepoznáváni“ do učitelského vzdèlávání. Nebot' jen diky živému spojeni osobni zkušenosti a reflexe může být vědèní z oblasti hlubinné psychologie využito kriticky-konstruktivně a müže mit praktický dopad. Pokud jde o hledáni vysokoškolského konceptu vzdèláváni učitelü, bylo by velmi užitečné, kdyby se známý „spor škol“ mohl promènit v kreativni dialog, který by zahrnoval nejen rüzné psychoanalytické smèry, ale také rüzné prístupy z oblasti humanistické psychologie.
\end{abstract}

Klícová slova: vzděláváni učitelư, hlubinná psychologie, psychoanalýza, analytická psychologie, individuálni psychologie, humanistická psychologie.

\section{ÚvoD}

Trápení ve škole a ze školy je bezmála archaický literární námět. $\mathrm{O}$ tom, že vychází z konkrétních zkušeností a s dějinami školství těsně souvisí, není pochyb. Jako raný prŕḱlad ambivalentního postoje $\mathrm{k}$ donucovacím způsobům ve výchově lze spatřovat známé odsouzení školy ve $V y$ znánich (Confessiones) svatého Augusti- na. Aurelius Augustinus v nich odsuzuje příkoří, jakého se mu dostávalo ve škole, byt ho nakonec přece jen pokládá za spásonosné v tom, že hříšníkovi zprostředkovává odstrašující ukázku pekla.

Moderní podobu dostává výchovně kritický diskurz v líčení fyzicky trestajícího učitele ve Chvále bláznivosti (1509) Erasma Rotterdamského. Erasmus tu precizně předjímá myšlenkovou figuru, jež 
bude později $\mathrm{v}$ psychoanalýze pojmově zařazena jako nutkání k opakování: Učitel coby obět se závažnou duševní újmou, již mu kdysi způsobila výchovná moc, ji nyní sám a $\mathrm{z}$ pozice silnějš́ího obrací vůči svým bezbranným žákům.

V novodobějších dějinách (1965) poukazuje Theodor W. Adorno stejně jako mnozí jiní na „nutnost psychoanalytické př́pravy a sebereflexe $\mathrm{v}$ učitelském povolání“. Jeho důrazný apel ale vyznívá téměř do ztracena. Jedním z možných důvodů je to, že psychologie (empiricky orientovaná) dokáže z jakéhokoli psychodynamického prrístupu ve školní pedagogice jen máloco vytěžit. Ostatně $v$ jednom $\mathrm{z}$ děl Psychologie pro vzděláváni učitelu je po stručném, sotva jednostránkovém odkazu na Sigmunda Freuda učiněn paušální výrok, navíc typograficky zvýrazněný jako poučka, že: „Prospěšnost uplatňování teorií hlubinné psychologie pro praxi ve školním kontextu je nutno označit za krajně omezenou" (Wisniewski, 2016, s. 43). - Opravdu?

Přesto existovaly a dodnes existují snahy zapojit hlubinně psychologické aspekty do pregraduálního vzdělávání učitelů. Ústřední myšlenky hlubinné psychologie a jejich představitelé (Freud, Adler, Jung) mezitím dostaly možnost sehrát na vysokých školách v rámci pedagogické psychologie poměrně konkrétní „teoretickou“ roli. Jinak to vypadá se zapojením sebereflexních - a z hlediska hlubinné psychologie nezbytných - komponent ve vztahu $\mathrm{k}$ vlastní biografii a se zkoumáním emočního hlubinného rozměru $\mathrm{v}$ pedagogických situacích jako důležitým aspektem, který se bezprostředně dotýká každého: žáka i učitele. Zde existuje určité dezideratum, ačkoli je možno najít i několik (málo) snah, k nimž lze v této souvislosti a pro formulaci rozvíjejících otázek a pokusů sáhnout.

\section{EMOCIONÁlNí JÁSTVÍ - ZA- NEDBÁVANÁ VELIČINA VE ŠKOLNÍ VÝCHOVĚ A VZDĚLÁVÁNÍ UČITELŮ}

Přes existující širokou shodu v mnoha otázkách ve věci pedagogických kompetencí a $\mathrm{v}$ koncepci vzdělávání učitelů je současně namístě konstatovat i závažné nedostatky. Zanedbávání emocionálních aspektů je těsně spjato $s$ některými dalšími skutečnostmi, jejichž kořeny obecně sahají hluboko do dějin školství a institucionální výchovy. Právě tyto kořeny mají za následek podceňování významu subjektivních at už explicitních, anebo skrytých - emocionálních reakcí dítěte a žáka, stejně jako učitele a vychovatele $\mathrm{v}$ procesu vyučování a učení se. $Z$ mého hlediska historicky nejdůležitější a institucionálně ukotvené důvody pro zmíněné zanedbávání jsou: a) orientace školní pedagogiky na většinovou kulturu, b) didakticko-metodická jednostrannost, c) stále silnější empiricko-behaviorální směřování výzkumu a výsledková orientace škol.

Ad a) Dědictví národnostně zaměřeného školního vzdělávání odvádělo pozornost od specifických potřeb zvláštních společenských skupin. Dělo se tak v první řadě pod záštitou jazyka většiny a pocitu národní kultury a společenství. Tento pocit byl vní- 
mán zčásti jako esenciální a osudný, zčásti byl pěstován poeticko-mytologicky a zčásti podněcován politickými nástroji. Otázky, jež s ním souvisejí, jsou předmětem diskusí už dlouhou dobu. Většinou však v souvislosti s momenty překonávání odporu k zajištění integrace menšiny (nebo menšin) do většinové kultury, přičemž se opomíjí její (jejich) vlastní - i religiózní - kulturní původ a identita.

Ad b) Cílenost vzdělávání pedagogů na metodickou monokulturu procesu vyučování a učení vedla - a to i přes některé jinak orientované jednotlivé snahy - $\mathrm{k}$ tomu, že alternativní školské koncepce a "subjektově senzitivní metody“ se ve vzdělávání učitelů tematizovaly jen okrajově. Inovativní potenciál takových koncepcí tím nachází jen úzké využití a pedagogický dorost pro alternativní školy musí být rekrutován většinou z institucí mimo státní akademická zařízení. Nezřídka pak v důsledku toho dochází $\mathrm{k}$ ideologickému zatvrzení alternativních pedagogických kruhů a $\mathrm{k}$ oslabování potenciálu nových prýstupů pro pedagogické inovace obecnè.

Ad c) Směřování př́ípravy učitelů na instrumentálně technické a behaviorální aspekty vyučování a učení se (empiricky př́stupné standardy a kompetence na straně učitele a empiricky měřitelné výkony na straně žáka) vedly $\mathrm{k}$ zúžení pohledu na duševní dění a na citové vztahy mezi učiteli a žáky ve výukovém procesu. To platí i přes dosažený pokrok v demokratizaci školství a přes posílení formálních participativních práv, jimiž se pozice zvláštních společenských skupin a subjektu vzdělávání (práva dítěte, ochrana dítěte, právo spolurozhodovat) celkově upevnila. G. Reimerová tak ve své práci Nevédomé vztahové formy mezi učiteli a žáky (2006) dochází k lapidárnímu závěru: „Vyloučení vztahové roviny zůstává zajištěno“" (tamtéž, s. 45).

Dominantní politicko-kulturní orientace tudíž nadále pišse určující roli většinové kultury a brání v utváření empatie zaměřené na jednotlivé dítě; omezená metodická kultura školy je překážkou v hledání alternativních pedagogických řešení, jež by lépe navazovala na individuální situaci dítěte; „orientace na výstupy“ předjímá podobu komplexního výchovného procesu způsobem, který stojí v cestě procesnímu pojetí výchovy, nahodilosti a emocionálnosti ve výchově $\mathrm{a}-\mathrm{v}$ důsledku dominance hlediska kognitivních cílů - výrazně omezuje kreativní prostor jejích „činitelü“. To všechno má zároveň omezující vliv na utváření a rozvíjení př́íslušného vědeckého společenství, jež by za dnešních institucionálních podmínek vzdělávacího systému a vědy mělo být odkázáno na podporu ze strany politiky a hospodářství. Také proto je okruh pedagogů a výzkumných pracovníků, kteř́ usilují o integraci psychologických hlubinně orientovaných prístupů a odpovídajících způsobů výuky vycházejících z (vlastní) zkušenosti do pregraduální př́pravy učitelů, mimořádně úzký. Pokud je mi známo, neexistuje $\mathrm{v}$ evropském prostoru řádná profesura, jež by se tímto výzkumným a rozvojovým úkolem zabývala. 
2. K PSYCHOLOGICKÉ HLUBINNÉ STRUKTUŘE PEDAGOGICKÝCH

INTERAKCÍ - HISTORICKÉ

A SYSTEMATICKÉ ASPEKTY

\subsection{O mocné síle předchozích zkušeností}

Hlubinná psychologie přesvědčivým způsobem ukázala, že o našich současných zkušenostech a jednání vysokou měrou (spolu)rozhodují stopy našich předchozích zkušeností. Často se jedná o stopy „skryté“, mj. z toho důvodu, že jejich obsahy nehrají v běžné komunikaci přijatelnou roli, a mnohdy by ji dokonce rušily. Pro funkcionální procesy společenského života nemá moje radost, mé trápení, můj vztek ani moje touha žádnou bezprostřední hodnotu. Co víc, většinou je považováno za vhodné držet je "pod pokličkou“, což platí zejména ve škole. Do sebeovládáni investujeme - více anebo méně vědomě - část své energie. Jedná se o kontrolu vlastních citů, př́edevším těch, jejichž vyjádření či existence je člověku samotnému nepř́ijemná nebo je společensky nežádoucí. Právě tomuto účelu slouží složitý soubor pravidel dobrých mravů a kultivovaného vystupování na veřejnosti. Dosáhnout tohoto „ovládání sebe sama ve svých afektech", aniž by to bylo za cenu emocionální ztuhlosti, lze jen tehdy, dokážu-li si sám udržet otevřený přístup ke svým emocím a - v souvislosti se školou - jen tehdy, je-li učitel schopen rozpoznat své vlastní slabiny, vlastní strachy a za určitých okolností také agresivní tendence a přiznat jejich (bezprostřední) přítomnost a existenci, stejně jako rozpoznat slabiny a obavy žáků. $\mathrm{Z}$ hlediska hlubinné psychologie by šlo (mj.) o to, rozvinout cit pro procesy „přenosu", tak aby učitel dokázal rozpoznat svůj vlastní podíl na problematických pedagogických situacích. A zde se zviditelňuje problém, který školu odedávna zatěžuje. Řeč je mimo jiné o otázce výkonu moci.

\subsection{Výchova a trestání - institu- cionálně zabezpečená vazba}

Vnést světlo do otázky mravní výchovy může pomoci historicky orientovaný pohled. Učitelské povolání od antiky např́ič celým středověkem nebylo schopno obejít se bez prostředku prrísné mravní výchovy a trestání. Učitel $s$ rákoskou $\mathrm{v}$ ruce bývá vypodobněn na mnoha výjevech ze školního vyučování. Rákoska je výrazem jednoty výuky/výchovy a trestání. Vedle ukazování - základní formy při výuce - slouží rákoska současně $\mathrm{k}$ zajištění disciplíny. Ještě dnes tu a tam svižně dopadne sice už ne na záda dětí, ale na hranu stolu a prostorem se rozlehne skličující ozvěna rádoby dávno zapomenutých časů. Jiné výjevy zobrazují drastické scény výprasku a chvíle, kdy jsou děti vystaveny ponižování ze strany svých spolužáků (oslovské a šaškovské čepice, sezení na dřevěném oslu, klečení na trojbokých hranolech). Takové praktiky zdaleka nepatřily $\mathrm{k}$ výstřelkům ojedinělých učitelů. Naopak, nacházely svou legitimnost ve vrchnostenských školních řádech. Doporučení vycházející z nahližzení Platóna a Augustina a nabízející se jako základní principy vyučování byla 
středověkému myšlení cizí: shovívavě nechat dítě dělat věci podle svého, $v$ počáteční výuce využívat potřebu hraní, sázet víc na "přirozenou zvídavost“ (Augustin) než na strach z trestu. Každodenní úkol učitele a jeho zkušenost $s$ krocením vzdorovitých žáků by se těmto zásadám jen vysmály. Už církevní otcové (Klement I., Órigenés, Řehoř z Nyssy) věděli, jak trestání teologicky ospravedlnit. Spásy člověka bylo možno dosáhnout jen poslušností před Bohem a před jeho zástupci na Zemi. $\mathrm{K}$ tomu navíc nutno prridat společensky vytvořený, hierarchicky odstupňovaný vztah mezi církví a státem, v jehož důsledku vyznívaly tehdejší mocenské poměry jako z Boží vưle dané a nedotknutelné. Církevní disciplína, státní moc, mravní výchova ve škole, to všechno byly momenty jednoho a téhož nutného a legitimního řádu.

\subsection{Náznaky nového myšlení v humanismu: sadistický učitel jako obět výchovné moci}

Teprve novému myšlení, jež vzniklo v humanismu, resp. v jeho základech leželo, se podařilo zpochybňováním tradice a autority - a tím i novým určením individuality coby jedinečného úkolu a díla sebe samé - znovu obrátit nezaujatý pohled do školních tříd a sejmout tělesně trestajícímu učiteli masku teologicko-pedagogického ospravedlnění. Ve svojí Chvále bláznivosti (1509) - abychom zmínili jeden vynikající př́klad radikálního kritika nepřiměřené mravní výchovy ve školách - nastavuje Erasmus Rotterdamský své době šaškovské zrcadlo. $\mathrm{V}$ satirické nadsázce, $\mathrm{z}$ níž je přesto jasně cítit, jak vážně je míněna, líčí mj. kantory jako zvláštní „druh lidí“. Jejich těžký úděl, který je váže na školní třídu („měl bych říct na dům trápení nebo ještě lépe šlapací kolo ${ }^{1}$ a mučírnu"), je snesitelný jen z milosti bláznovství, jež v nich probouzí víru, „že stojí na vrcholu lidstva. A jak dobře jim dělá zastrašovat to bázlivé hejno hrozivým výrazem a hlasem, proutkem, hůlkou a řemenem... To se jejich bída mění $\mathrm{v}$ přepych, ... služba v panování (Erasmus, 1960, s. 103f). A po vylíčení vlastního utrpení ve škole vyjadřuje ve svém pojednání o výchově chlapců, tentokrát však bez roušky satiry, svůj odpor k oněm „nevzdělaným katovým pacholkům“, kteří „jsou bezcitní, výprask udílejí pro povyražení a jsou utvořeni tak děsivě, že jim cizí muka působí potěšení " (citace dle Ballauff, 1969, s. 602). Na to, že toto „utvoření “ má společenské a generační vazby, a není tedy dáno od prírody, naráží Erasmus opět v souvislosti s vlastním prožitkem. Činí tak v místě, kde se zmiňuje o jakémsi teologovi „velkého jména“, „jemuž byla každá príísnost vưči žákům malá, nebot́ jeho vlastní učitelé propadli tělesnému trestání" (tamtéž). Nejedná se zde jen o nové popisování všeobecně známých jevů, rozvíjejí se tu nové snahy o objasnění. Na tomto místě se nabízí psychologický portrét člověka, jenž se v sadistickém aktu snaží najít klamný pocit vlastní velikosti

\footnotetext{
${ }^{1}$ Pozn. př̌kladatelky: Tretmühle, starověké šlapací kolo poháněné lidskou silou a používané k čerpání vody ze studní nebo jako pohonná jednotka např. mlýnů.
} 
a moci, aby jím kompenzoval své postavení na okraji společnosti a latentní pocity své méněcennosti. Člověka, který touží překonat vlastní traumatické zážitky z dětství a mládí tím, že je stejným způsobem činí těm, kdo mu jsou podř́zeni. Psychoanalýza dnes v této souvislosti mluví o „nutkání k opakování“.

\section{4 „Př̀nos" - na cestě k psychodynamicky objasněném pohledu na vztah učitel-žák}

Do rozsáhlejšího zkoumání psychické dynamiky výchovného procesu - vedle neutuchajících apelů na humanizaci učitele od Erasmových dob až ke „správnému“" pedagogickému postoji a pozdějším (převážně) idealistickým diskurzům o ,pedagogickém prrístupu“ (H. Nohl) - muselo samozřejmě uplynout ještě několik staletí. Umožnil ho teprve rozvoj psychoanalýzy a psychoanalytické pedagogiky (výrazněji po 1 . světové válce). Pojem „přenosu“ - připravený již u Erasma, jak je patrno výše - se přitom ukázal jako mimořádně osvětlující v poznání, že (podobně jako při settingu v psychologické terapii) existují v pedagogických vztazích účinné momenty, které vedou ke „zkresleni“ vnímání a komunikace. K této distorzi dochází promítáním neboli „přenosem“ vlastních (a většinou nevědomých) obav, tužeb, předsudků a agresí na aktuální protějšek v komunikaci nebo do aktuální situace. Tento proces je silně oboustranný. Jinými slovy, tendenci k přenosům má také žák/žákyně.

V klasickém chápání hlubinné psychologie znamená „přenos“ zpočátku nevě- domý sklon analyzanta přenášet do vztahu ke svému analytikovi vztahové vzorce z raného dětství. Analytik se tak může stát projekčním plátnem pro vnitřní obraz (,imago“) „zlého otce“, „nelaskavé matky" nebo ještě obecněji pro obraz světa bez lásky. Oklikou přes přenos a jeho poznání, propracování a interpretaci lze nastartovat proces léčby; „zkreslujíci“ vliv uvedených momentů na situace každodenního života by měl v jejím výsledku skončit.

Přenosy jsou častým průvodním momentem - někdy více, jindy méně silným - v komunikaci s druhými. Ve školním prostředí se někdy stává, že se děti $\mathrm{v}$ prvním a druhém roce školní docházky obracejí na svoji učitelku, ale i na svého učitele výrazem „mami“. Občas si onu „chybu“ samy uvědomí a s úsměvem ji opraví, jindy ji nepostřehnou. Ovšem i tam, kde k takovému „přeřeknutí nedochází, odpovídá jejich obraz učitelky mnohdy jejich vztahu $\mathrm{k}$ vlastní matce. $\mathrm{O}$ tom, že se jedná o přeřeknutí, není sporu, nicméně nahlížet je jako chybu se dá jen v omezeném smyslu. Důvodem je to, že učitelka může nést veskrze znaky milující a starostlivé osoby, tj. podobné, jaké má ta skutečná/vytoužená, „dobrá" anebo - řečeno slovy Winnicotta - „dostatečně dobrá matka“.

Na občasné libidózní okamžiky ve vztahu mezi učitelem a žáky (žákyněmi) zřetelně poukazuje $A$. S. Neill v názorném příkladu z vlastní praxe. Př́íhoda se mu stala někdy počátkem dvacátých let 20 . století. „Přednášel jsem psychologii u dívek z oddělení eurytmie. Jednoho dne za mnou přišla do kanceláre mladá Ruska z eurytmického oddělení, zprudka mne objala a řekla: 
,Pane Neille, já vás miluji. Já sám jsem ani neznal její jméno a byl jsem z toho trochu zděšený... Když ale žena pokračovala slovy: ,Napsala jsem o tom svému muži a v sobotu přijede, aby se $s$ vámi utkal $\mathrm{v}$ souboji na pistole,moje zděšení přešlo $\mathrm{v}$ paniku... To nebohé dítě si ke mně vytvořilo přenosový vztah a vystavělo si kolem mne celý vzdušný zámek" (Neill, podle Hermann, 2012, s. 254).

Úkolem dítěte - při němž mu učitelka může a měla by být opatrně nápomocna - je postupně si uvědomovat rozdíl mezi matkou a učitelkou a dorůst do takového vztahu, který bude odpovídat skutečným rolím a okolnostem. Jedná se o poznenáhlý vývoj, který je sotva uvědomovaný a definicemi rozhodně často neuchopitelný. Dítě a dospívající prochází trvalým procesem určité psychoanalýzy: Mladý člověk tyto přenosy funkcionálně (a tedy nikoli bezpodmínečně vědomě) postupně ruší a propracovává se $\mathrm{k}$ realistickým nebo $\mathrm{k}$ alespoň částečně realistickým postojům. Řeč je o základní podmínce úspěšného vývoje a socializace. Jde o to, že ve školní situaci je dítě v první řadě nikoli dítětem, ale školákem anebo školačkou. Romantizující pedocentrická „pedagogika vycházející z dítěte“ si tento rozdíl mnohokrát odmítá připustit, a stojí tak v cestě potřebným procesům diferenciace ve vývoji dítěte. $\mathrm{K}$ „př̌nosu“ dochází samozřejmě také na straně učitele a učitelky. Přenos nastává, když pedagog vnímá svůj protějšek anebo (komplexní) situaci na základě svých (nevědomých) potřeb. Jinými slovy, vnímá ji zkresleně - a nerozpozná, že se jeho protějšek stává nástrojem $\mathrm{k}$ uspokojení jeho vlastních potřeb, např. $\mathrm{k}$ uskutečnění fantazijních představ o vlastní moci (viz zmíněný př́ípad Erasma). Navíc se to však děje pod pláštíkem pedagogické legitimity. Jak už Erasmus naznačuje, př́činou může být podobná vlastní tragická zkušenost.

„Sklon“ ke vzniku přenosových vztahů však nevykazuje jen psychoanalyticko-terapeutický vztah - pro analytika je dokonce očekávaným vztahovým momentem, jenž prostř̌ednictvím poznání a interpretace může být $\mathrm{v}$ procesu léčby př́nosem. Rovněž ambivalentní struktura „blízkosti a vzdálenosti“ (srov. Herrmann, 2012, s. 253 a další) ležící uvnitř pedagogického vztahu a většinou i jeho dlouhodobé trvání vytvárejí vhodnou živnou půdu, z níž mohou vzejít nepoznané přenosové vztahy mající latentní a někdy dokonce i zhoubný účinek.

\subsection{Adornova výzva k psycho- analytickému „vzdělávání a sebereflexi $v$ učitelském povolání"}

Všechny tyto souvislosti se $\mathrm{v}$ období po druhé světové válce znovu a výrazněji ocitly ve středu pozornosti teprve až v šedesátých letech 20. století. Mimo jiné jako pozdní následek dlouhotrvajícího potlačování psychologických aspektů traumatických zkušeností z období nacionálního socialismu. Uváděny byly většinou $\mathrm{v}$ rámci kapitalisticky kritické a neomarxistické kulturní kritiky. V této souvislosti je namístě připomenout Theodora W. Adorna.

V květnu 1965 - v „předvečer“ antiautoritárního studentského hnutí a emanci- 
patorních hnutí založených na principech demokracie - vystoupil Adorno v Institutu Maxe Plancka pro výzkum v oblasti vzdělávání s přednáškou na téma „Zapovězené otázky o učitelském povoláni'“. V jejím textu obšírně uvádí: „Již v mateřské škole se často stává, že je dítě vytrženo ze své primární rodinné skupiny, z prostředí bezprostředních, pečujících a srdečných vztahů, a dochází $\mathrm{k}$ jeho nečekanému, šokovému střetu s odcizením. Činitelem takového odcizení je autorita učitele, reakcí na ně pak negativní obsazení jeho imaga (rozuměj obsazení obrazu učitele v dítěti - E. S.). Učitel $\mathrm{v}$ dětech prosazuje civilizovanost, nutí je vzdávat se určitých věcí a to všechno $\mathrm{v}$ dětech automaticky mobilizuje imagines učitele nahromaděné $\mathrm{v}$ běhu dějin, které se stejně jako každý jiný odpad přetrvávající v nevědomí mohou podle potřeb psychické ekonomie znovu probudit... Co se děje ve škole, je $\mathrm{v}$ podstatě na hony vzdáleno toužebným očekáváním. A učitelské povolání v tomto smyslu samo archaicky zaostalo za civilizací, již zastupuje..." (Adorno, 1965). V dalším textu Adorno rozvášněně nastiňuje nevýslovný boj mezi žákem a učitelem a antimonii dané situace - aby vzápětí nalezl následující východisko: „Pomoci by proti tomu mohl ... jedině změněný způsob chování učitelů. Učitelé nesmí své vlastní emoce potlačovat a pak je nakonec racionalizovaně ventilovat. Naopak, sami před sebou i před ostatními je musí přiznat a žáky tím odzbrojit... $\mathrm{Z}$ takových reflexí bezprostředně plyne ... nutnost psychoanalytického vzdělávání a sebereflexe v učitelském povolání“ (tamtéž).
Dilema částečně popsané již Erasmem ted' Adorno na základě neomarxistické sociální filozofie staví do psychoanalytické perspektivy. $V$ naší souvislosti stojí za zmínku především dva aspekty. Tím prvním je připomenutí oněch „bezprostředních“, „srdečných vztahü“ v „primární skupině“ - nostalgická šifra vize překonání odcizení vytvořením jiného světa bez represí a bez odcizení. Druhým aspektem je „odzbrojení odporujícího žáka lidským odhalením sebe sama a „změnou způsobu jednání" na straně učitele. Rozpozná-li učitel př́ćcinu svého autoritárního a represivního chování a pomocí psychoanalytického školení ji nakonec zneutralizuje, pak také žáci odloží svoje „zbraně“. Autoritarismus ve škole by tak byl zdolán, onen nevýslovný boj by skončil a $\mathrm{v}$ prostoru bez represí či jen $s$ minimem represí by se pak obě strany mohly věnovat vzdělávání ne-odcizeného člověka. A rozvíjet tak lidské základy budoucí, ne-odcizené společnosti. Psychoanalyticky „vyvolaný" pedagogický bod zvratu ke klidu zbraní je tak lokalizován $\mathrm{v}$ psychice učitele.

Adornova naléhavá obhajoba psychologicky-osvícenského „vzdělávání a sebereflexe" má své kořeny jistě i ve zkušenosti s totálním a instrumentálním rozhodováním ze strany cizích osob, s níž se v diktaturách 20. století musel vyrovnávat bezpočet lidí. Je pochopitelné, že se Adorno v Institutu Maxe Plancka setkal u výzkumníků působících na poli vzdělávání jen se sporým zájmem. „A tak se i tam rozvinul empirický výzkum vzdělávání: Už desítky let se pracuje se stále stejnými kvalifikacemi a kompetencemi učitelů, zatímco 
psychologicko-psychoanalytická dimenze učitele $\mathrm{v}$ pletivu jeho vnějších a vnitřních vztahů zůstává z velké míry terra inkognita, stále ještě ta Bernfeldova hranice výchovy ve vychovateli..." (Herrmann, 2012, s. 249). Tak se stalo, že oblast, jejíž zapojení se mělo a mohlo stát mj. legitimujícím a obsahovým základem pro koncepci prvků Adornova zamýšleného „vzdělávání a sebereflexe" učitele, zůstala nevyužita.

\section{PSyChOdYNAMICKÉ PŘíSTUPY}

\section{SEBEPOZNÁVÁNí A SEBEREFLEXE}

VE VZDĚLÁVÁNí UČITELŮ

Tato záporná bilance samozřejmě neplatí všude a všeobecně. Důvodem je, že prvky hlubinně-psychologicky nebo psychodynamicky orientované sebereflexe - částečně i jako výsledek pozdních šedesátých let 20. století - přece jen do vzdělávání učitelů „prosákly“. Zajímavé přitom je, že se zde nejedná jen o diskusi v teoreticko-pojmové rovině, jež si alespoň v náznacích a často prostřednictvím studijních řádů našla své místo téměř ve všech seminárích a přednáškách o pedagogice a pedagogické psychologii, ale o zařazení sebepoznávání coby reflexe vlastní biografické nebo pedagogické zkušenosti ve vztahu $\mathrm{k}$ procesům přenosu. Pohled na procesy biografického anebo profesního sebepoznávání ve spojitosti s otázkou psychodynamických aspektů vychází z předpokladu, že - obdobně jako je tomu u psychoterapeutické př́pravy jakéhokoli směru - je pro hlubší pochopení těchto př́stupů vedle práce $s$ teoretickými pojmy nezbytně nutné tematizovat vlastní zkušenosti, jež se $\mathrm{k}$ těmto pojmům vztahují. To platí v každém př́ípadě tehdy, slouží-li k odbornému sebepoznávání, nabývají na praktické relevantnosti a $\mathrm{v}$ určitém prrípadě mají utvářet kriticko-konstruktivní zkušenostní základy dalšího výzkumu.

\subsection{Strach učitele ze svého žáka (Horst Brück)}

Horst Brück vydal v roce 1978 (v nakladatelství Rowohlt) zprávu o svém působení jako vysokoškolského docenta na univerzitě v Gießenu, jež vyvolala značnou pozornost: Strach učitele ze svého žáka s podtitulem $K$ problematice zbývajici dètskosti ve výukové práci učitele - model. Působivě a obšírně v ní popisuje, jak se v rámci semináŕů a hospitací při výuce a $\mathrm{v}$ následných pohovorech sloužících $\mathrm{k}$ přípravě na praktickou výuku nechají vysledovat osobnostní složky, jež se - jako pozůstatky (původně) potlačených poranění duše v životě konkrétního jedince - (spolu) podílejí na určování charakteru dnešního výukového procesu, zatěžují ho nebo ho mohou dokonce i zmařit. Cíl spočívá podobně jako u psychoanalyticky terapeutického postupu v tom, aby se tyto momenty „zbývající dětskosti“ pomocí asociativních a reflexivních procesů rozpoznaly, iniciovala se „dodatečná výchova“ a tyto momenty $\mathrm{v}$ jejím důsledku přestaly pedagogickou interakci determinovat, nebo ji alespoň $\mathrm{v}$ takové míre nezatěžovaly. - Pokud je mi známo, uvedený „model“ byl svého času předmětem mnohých debat. Další vysoké školy ho ale nepřevzaly a na jeho dalším 
rozvoji nepracovaly. Je však využit (a možná posloužil i jako zdroj inspirace) pro níže představený prrístup „scénického chápáni“ Achima Würkera.

\subsection{Reflexivní sebepoznávání (Univerzita ve Flensburgu)}

Z osobních zkušeností získaných při provázení praktikantů, ale i na seminárích $\mathrm{k}$ rozvoji vnímacích schopností jsem došel $\mathrm{k}$ přesvědčení, že ve vztahu mezi žákem a učitelem mají $\mathrm{v}$ př́pravě učitelů velký význam psychodynamické procesy. A to nejen když se jeví jako bezpodmínečně nutné uplatnit terapeutické nebo pedagogicko-terapeutické prrístupy, ale i v „normálních“ školních situacích. $\mathrm{V}$ průběhu asi deseti let (2002-2012) se tak vyvinula koncepce seminárự, jejímž záměrem bylo vytvořit pomocí jednoduchých a komplexnějších cvičení prostor k nabývání zkušeností, umožňující zkoumat základní psychické aspekty dynamiky vnějšího a vnitřního světa. Tuto koncepci nazývám „reflexivní sebepoznávání“ (Skiera, 2011). Záměrem uvedeného př́stupu je ztvárnit chráněný prostor pro setkávání, $\mathrm{v}$ němž bude existovat možnost ke zkoumání a prohlubování vztahů mezi vnitřním a vnějším světem. Cestou cvičení má vzniknout tvůrčí prostor pro akci, komunikaci a reflexi, kde psychická hlubinná dimenze našeho vnímání a jednání vstoupí do našeho vědomí výrazněji než v běžných situacích pracovní a mimopracovní každodennosti.

Formulace takového cíle má pro učitele z psychologického hlediska zcela ur- čitě mimořádný význam, nebot živý kontakt k vlastnímu nitru musí být ve škole chápán jako nezbytný základ pro rozvoj prospěšného a na empatii založeného vztahu k žáku/žákyni. Koncepce samotných cvičení je však připravena tak, aby pozornost nebyla směřována explicitně k hlubinně-psychologickým aspektům, a to ani při podávání zpráv o získaných zkušenostech a jejich interpretaci. Není zde explicitní orientace na nedostatky a problémové jevy. Jedná se čistě o to vytvořit "chráněný prostor" (bez tlaku na výkon a bez nucení $\mathrm{k}$ účasti a sdělování pocitů - zdráhavý účastník smí na své přání prostě jen prrihlížet ostatním při cvičeních) jako „volné pole k hraní“, kde vznikne možnost vysledovat emocionální rozměr sociální oblasti ve smyslu (pokud možná) ne-předjímajícího fenomenologického př́stupu. Jedná se o vývojově otevřenou koncepci, do níž jsou vedle řady jiných zahrnuty podněty ze "Sensory Awareness" od Charlotty Selverové, z "Gindler-Arbeit" (od Elsy Gindlerové pro školení k uvědomění si těla) a cvičení divadelního pedagoga Jurije A. Vasiljeva (zkoumání souvislosti mezi pohybem, hlasem, zvukem a emocemi; Skeira, 2011).

Abychom uvedli nějaký př́klad, zmiňme na tomto místě jen jedno komplexnější cvičení: Setkat se s dítětem a žít s ním - symbolická cvičení kontaktu a komunikace s „vlastním“ dítětem (tamtéž, Lekce 13). Cvičení tvoří deset stanovišt. Stanoviště jsou označena pomocí karet $s$ úkoly a vybavena různým materiálem, např. panenkou představující „vlastní 
dítě“. Úkolem je „strávit s dítětem den“ (hrací situace trvá 20-25 minut). Zda v průběhu cvičení a s ním souvisejících úkonů a řečových aktů (součástí je rovněž jeden „akt zpěvu - ukolébavka“) opravdu vznikne symbolický přenos nebo „nabití" emocionálními vnitřními obsahy $\mathrm{z}$ vlastního životního př́iběhu, nelze ani říct, ani určit předem. Pakliže však $\mathrm{k}$ němu dojde, otevírá se tím možnost navodit procesy uvědomování si vlastních postojů $\mathrm{k}$ nejrůznějším sociálním aspektům, především ale $\mathrm{k}$ těm, jež nastávají př̀i výchově dětí, jako je zdravení, zaopatřování, chránění, učení, vysvětlování a další. Ve skutečnosti dochází $\mathrm{k}$ symbolickým přenosům velmi často, a to nejenom u toho, kdo cvičením právě prochází (praktikanta), ale i u jeho prrítomného průvodce a "asistenta“. Ten sám cvičení absolvoval krátce předtím, praktikantovi vysvětluje průběh cvičení v prostoru, proces sleduje a na přání praktikanta mu později může poskytnout i zpětnou vazbu.

V rámci hlubinné psychologie lze při použití „reflexivního sebepoznávání hovořit o psychodynamické propedeutice, kde se velice otevřeným a teoreticky (zatím ještě) nesystematizujícím způsobem poznává emocionální rozměr sociální oblasti formou cvičení a následné reflexe.

\subsection{Integrace dětí a mladistvých $s$ emocionálními a sociálními problémy $\mathbf{v}$ kontextu školy (Vídeňská univerzita)}

V informativním př́spèvku Sila emoci ve výuce: Psychoanalyticko-pedagogická studie podává Margita Datlerová (2012) zprávu o různých pokusech $\mathrm{v}$ minulosti i současnosti, jak do př́pravy a dalšího vzdělávání pedagogů zavést psychoanalyticky zaměřená kurikula. Uvedené snahy vycházejí především z ohledu na problematické pedagogické situace a terapeuticko-pedagogické úkoly a jsou pojaty jako postgraduální studium či další vzdělávání. Totéž platí i pro šestisemestrální magisterské studium $\mathrm{v}$ rámci dalšího vzdělávání (120 ETCS) „Integrace dětí a mladistvých $s$ emocionálními a sociálními problémy v kontextu školy“, na jehož vzniku má zásadní podíl Wilfried Datler, jenž ho i sám vede. Studium je od zimního semestru 2010/2011 zařazeno do nabídky Vídeňské univerzity (Datler, 2012, s. 209 a další). Jedná se o diferencovaný př́istup, kde každý $\mathrm{z}$ modulů pracuje s psychoanalyticko-pedagogickými modely chápání: „sledování na základě tavistockého prrístupu, prípadové diskuse, work discussion, supervize, sebeuvědomování $\mathrm{v}$ malých skupinách, vlastní uvědomování, skupinová výuka reflexe, rodičovské poradenství, individuální a skupinová práce $s$ žáky, výuka $\mathrm{v}$ malých třídních kolektivech..., krizová intervence ve školách, spolupráce se školskými a mimoškolskými institucemi“ (tamtéž).

Výsledky tohoto studia jsou napjatě očekávány. Právě z něho by totiž vedle dalších zkušeností mohly vzejít podněty pro koncepci vzdělávacích kurikul, jež by do pregraduální prrípravy budoucích pedagogů obecným způsobem a pro všechny vtělila psychoanalytické (nebo obecněji: hlubinně-psychologické) poznatky, myšlení a zkušenosti. 


\subsection{K integraci aspektů indivi- duální psychologie do prŕpravy učitelů (Jürg Rüiedi, Švýcarsko)}

Ze všech tří základních škol hlubinné psychologie, tzn. psychoanalýzy Sigmunda Freuda, analytické psychologie Carla Gustava Junga a individuální psychologie Alfreda Adlera, měla ve školství z dějinného hlediska největší vliv bezpochyby poslední jmenovaná. Hlavním zprostředkovatelem jejího vlivu byl Adlerův žák Oskar Spiel (Spiel, 1947/1979), zatímco v politické rovině ji výrazně umožnil a podpořil Otto Glöckel, velký školní reformátor ve Vídni dvacátých a raných tríicátých let 20 . století. Stejně jako i u ostatních hlubinně-psychologických snah se však individuální psychologie nedokázala $\mathrm{v}$ př́pravě učitelů etablovat udržitelným způsobem. Přesto lze zmínit jeden zřetelný pokus mladšího data, který nicméně - jak se v této oblasti často stává - nepřetrval věkem podmíněný odchod svého iniciátora, Jürga Rüediho, z vysokoškolského prostředí.

V roce 1995 předložil Rüedi svoji zprávu o získaných zkušenostech Individuálně psychologická príprava učitelek a učitelü. Poté, co v ní popsal institucionální podmínky ve Švýcarsku, poznamenává, že o zařazení individuální psychologie a způsobu její integrace rozhoduje konkrétní docent a „individuální biografie jeho vzdělání". Rüedi zde líćí vlastní př́stup $\mathrm{k}$ individuální psychologii - sám je $\mathrm{v}$ tomto směru vystudovaný psychoterapeut - a nastiňuje svou akademickou teorii ve znamení individuální psychologie $\mathrm{v}$ souvislosti $s$ výběrem témat a obsahů seminárních prací při své výuce pedagogiky a psychologie a ve vztahu k vlastnímu postoji coby vysokoškolského učitele obecně. $\mathrm{V}$ názvu tohoto prríspěvku je předznamenáno „Po stopách“ a v tomto smyslu nacházíme i v Rüediho zprávě snahu o sebepoznání, konkrétně jako „cvičeni“ k vyjasnění jednoho $\mathrm{z}$ adlerovských konceptů. Jedná se $\mathrm{v}$ něm o vhled do ,spojitosti mezi (osobním - E. S.) konceptem schopnosti, odvahou a připraveností $\mathrm{k}$ výkonu, popř́padě strachem ze selháni" (tamtéž s. 28), které lze nejenom ozřejmit $\mathrm{v}$ teoretické rovině, ale také navodit hrou. "Ještě názorněji (jako teoretické vysvětlení - E. S.) poslouží uložit některému ze studentů úkol, aby vhodil míč do koše, a poté se $s$ ním zamyslet, proč házel $\mathrm{z}$ konkrétní vzdálenosti“ (tamtéž). Tento prostý prríklad zároveň ukazuje - a je to naznačeno $v$ obratu „s ním“, tzn. se studentem -, že se zde při hlubinně-psychologickém náhledu jedná o interpretační snahu, jejíž hermeneutická hodnota je rozhodujícím způsobem závislá na spoluúčasti „probanda“. To, co se totiž př̀i hodu z „hlubinné dimenze“ ještě vyjeví nebo bude přeneseno do vědomého stavu, lze zprostředkovat jedině pomocí analýzy, která vedle akutního zážitku a společně s ním zapátrá po otiscích předchozích zkušeností: jako možnosti „vnášeni“ dř́ve nebo doposud nevědomých obsahů do konání jedince.

Pokud je mi známo, Rüedi svůj zážitkový př́istup jako směr nebo seminární koncept už dál nerozvíjel ani netestoval. Snadno si ale můžeme představit, že by se prostřednictvím experimentálních situací formou akce, hry na role či psychodrama- 
tu apod. mohly do konkrétní zkušenostně zaměřené perspektivy dostat i další relevantní koncepty adlerovského pohledu, jako např́klad komplex méněcennosti a kompenzace, individuální životní cíl nebo smysl života, sociální zájem a pocit sounáležitosti, kreativita, sebeochrana a maskulinní protest, význam pořadí narození mezi sourozenci a další. Stejně jako u všech hlubinně-psychologických př́stupů by předpokladem byla př́slušná didaktická kompetence na straně vyučujícího.

\section{$3.5 \mathrm{~K}$ integraci přístupů $\mathrm{z}$ analytické psychologie C. G. Junga do př́pravy učitelı̊}

Rovněž Carl Gustav Jung se stejně jako Freud a Adler př́ležitostně vyslovoval $\mathrm{k}$ otázkám výchovy. Ve své přednáškové řadě Analytická psychologie a výchova, s níž v květnu 1924 vystoupil v Londýně, se polemicky vymezuje vůči freudovskému př́stupu a zejména vůči jeho teorii pudu a libida, která „naprosto inteligentní lidi“ svádí $\mathrm{k}$ nejednomu „kauzalistickému nesmyslu“, jako že třeba „vídeňský kostel svatého Petra není nic jiného než potlačená dětská touha po stromu poskytujícím ochranu“ (Jung, 1926, s. 66). Proti „teorii potlačování staví Jung svou vlastní „teorii vývoje“. Nevědomí, onen „stín“, není pro něj pouhým zdrojem bolestných zážitků a patologických vývojů (jímž „stín“ může rovněž být), leč právě i zdrojem bezmála nevyčerpatelné a nikdy nezměřitelné kreativity (tamtéž, s. 62 a další). „Nevědomi“ je podle Junga „věčně plodná matka vědomí (tamtéž, s. 67). Tato „matka“ je v pod- statě tvořena „kolektivním nevědomím“, místem, kde se $\mathrm{v}$ jednotlivci po generace energeticky zhuštují duševní zkušenosti. „Zděděný mozek je výsledkem ancestrálního psychického života" (tamtéž, s. 69). Nad tím vzniká „infantilní vrstva osobního podvědomi" (tamtéž, s. 68). Tato vrstva je přetrvávajícím substrátem oné části osobních prožitků, která byla bud' potlačena, nebo postupně zapomenuta.

Jungem citovaná dětská potřeba ochrany je živým př́kladem hlubinně-psychologického myšlení vůbec. Možná se Jung snaží v očích Freudových následovníků zesměšnit onen „kauzalistický nesmysl“ ve smyslu „nic jiného než“ (viz výše). Sám ovšem, stejně jako Adler, bude v rámci svého psychologického pohledu na člověka sotva moci poprít prvopočátečni souvislost mezi potřebou ochrany (a přetrvávající touhou po bezpečí ve společenství, ve spiritualitě anebo $\mathrm{v}$ kosmu) a budováním monumentálních sakrálních staveb.

$\mathrm{V}$ jednom ze školních pokusů připisovaných „progresivnímu vzdělávání", který proběhl ve „Walden School“ v New York City (soukromá škola zde existovala v období 1914-1988), byla explicitně využita analytická psychologie. Jak už samotný název signalizuje - škola měla vazbu na amerického transcendentalistu Henryho Thoreaua, autora civilizačně kritického díla Walden aneb Život v lesich (1854) a vynálezce pojmu „občanská neposlušnost“. Jedná se o školu, jež (řečeno slovy Freuda) chce proti síle „superega“ postavit prostor tvořivosti $\mathrm{k}$ rozvinutí osobního vývojového potenciálu školáků a učitelů. „Učitelé Walden School, inspirovaní psy- 
choanalýzou a hlubinnou psychologií, se pokusili vytvořit prostředí, ... které by bylo zbaveno represí či útisku" (Gitz-Johansen, 2016, s. 368).

Zvlášt pozoruhodná je $\mathrm{v}$ naší souvislosti skutečnost, že se jungovské analýze podrobily vůdčí osobnosti reformní školy a $\mathrm{v}$ počátečních letech také většina učitelstva. Zakladatelka školy Margaret Naumburgová zastávala názor, že chápat citový život dítěte dokáže učitel jen tehdy, jestliže má probádány své vlastní emoce. $S$ ohledem na specifickou prrípravu na práci ve škole tak jungovská analýza (nejprve u jedné z ženských zakladatelek směru v USA Beatrice Hinkleové) sehrála rozhodující roli. - Vlastní hlubinně-psychologická analýza coby významná součást přípravy na učitelské povolání? O takové možnosti by se dalo dost dobře uvažovat, byt by její širší realizace byla z nejrůznějších důvodů, které zde nelze bliže objasňovat, zřejmě jen sotva možná. Přesto z hlubinně-psychologického hlediska zůstává úkolem umožnit odbornou „sebereflexi“ učitelstva. $Z$ hlediska analytického přístupu C. G. Junga bychom měli zkoumat pedagogický význam ústředních pojmů, kam patří již zmíněný „stín“, archetypální postavy coby dynamické strukturální momenty duševních pochodů (animus, anima, moudrý stařec, velká matka, hrdina apod.), s archetypy úzce spjaté kolektivní nevědomí a především pojem individuace jako osobní životní a vývojový úkol. (Srovnej také Semetsky, 2013.)

Osobně mi není znám žádný pokus $\mathrm{z}$ nedávné minulosti, $\mathrm{v}$ němž by došlo $\mathrm{k}$ zařazení prrístupu jungovské analýzy a pojmosloví do konceptu vysokoškolské didaktiky sebepoznávání pro studenty pedagogiky. Stejně tak celé roky stále rozpracovávaný „archetypální př́stup Clifforda Mayese (2017) zůstává z podstatné části na úrovni učení a slouží spíše jako teoretický interpretační rámec, abychom rozpoznali „náš psychospirituální cíl“ (our psychospiritual goal) a ve smyslu „transformative education" napomáhali jeho uskutečňování. Autor působí v jednom z pedagogických institutů v Utahu (USA) s křestanskou konfesní orientací. Roli učitele i sebe sama chápe jako „archetypálního moudrého starce“, jenž se coby zkušený "guide on our intellectual treck“ (tamtéž, s. 65) snaží podporovat studenty v procesu individuace a přispět tak $\mathrm{k}$ rozvinutému vědomí jejich pedagogického povolání (,calling as a teacher“, tamtéž s. 60).

\section{6 „Scénické chápání“ - profe- sionalizace pomocí psychoanaly- ticky orientované sebereflexe (A. Würker)}

Achim Würker rozvinul svůj koncept pro praktika psychoanalyticky orientované profesionalizace na Technické univerzitě Darmstadt a představil ho v jedné rozsáhlé práci (Würker, 2007). Jeho koncept je založen na pojmu „scénické chápání“, jehož popis pochází od psychoanalytika, sociologa a sociálního psychologa Alfreda Lorenzera. V konceptu se rozlišuje několik úrovní: chápání mluveného slova, tedy porozumění (sémantické, v podstatě lexikální) a také chápání (zjevných) intencí; chápání rečnika, tedy pochopení $\mathrm{v}$ řeči 
aktivovaných emocionálních obsahů zejména jako výraz v situaci nakažlivých (a situaci spoluutvárejících) neformálních a formálních sociálních vztahů; chápání situace jako celku, tzn. pochopení vlastní „scény“" s řadou ovlivňujících veličin, podmínek, dříve vtisknutých a nyní aktualizovaných vzorců chování a rolí apod.; a nakonec chápání (pi̛vodně) skrytých prání, (agresivních stejně jako libidózních) pudových hnutí, obranných postojů, latentních intencí. Čtvrtá z úrovní představuje samotné pole „hlubinně-hermeneutického chápání“. Vzhledem k její „skrytosti“ - skryta zůstává především spontánně jednajícím, ale možná i hlubinně-psychologicky školenému oku „nezúčastněného“ pozorovatele - je hlubinně-hermeneutické chápání odkázáno na následný proces reflexe. Tento proces může být zase úspěšný jen tehdy, bude-li hlasům (a rozpoložení) vlastních aktérů „scény“ přiznán rozhodující význam. (Stejně tak jako proces hlubinně-hermeneutického chápání může být zase chápán jako „scéna“ - a př̀i supervizi zúčastněným/i docentem/docenty musí být mimo jiné také tak brán.)

Metodické jádro würkerovského príistupu spočívá $\mathrm{v}$ následné, seminární formou prováděné hlubinně-hermeneuticky orientované reflexi zkušeností nabytých studenty $\mathrm{v}$ průběhu školního praktika. Obtížnost úkolu nyní spočívá $\mathrm{v}$ tom, jak získat co nejvíce "necenzurovaný" materiál, který se $\mathrm{v}$ rámci seminární skupiny a v součinnosti s ní nechá podrobit následné analýze. Tento materiál by měl př̀edstavovat hlas svého autora - aktéra, ovšem způsobem, jenž na rozdíl od terapeutic- kých situací ochrání autorovu anonymitu. $\mathrm{V}$ opačném př́ípadě by hrozilo přilišné riziko autocenzury a toho, že by se z hlubinně-hermeneutického pohledu symbolizovaly, tzn. rozebíraly jen nepodstatné věci (nap̌r. z racionálně dostupnějších úrovní „scény“) - jak tomu ostatně bývá u obvyklých písemných zpráv $\mathrm{z}$ absolvování praktika (koneckonců jde přece o to získat dobrou známku, a tak člověk chce a musí předvést, že ve svém „řemesle“ - připravit vyučovací hodinu a úspěšně ji realizovat už také dosáhl pokroku).

Z možných postupů symbolizace zkušenosti se Würker rozhodl pro písemnou formu, přesněji řečeno pro spontánní a právě pokud možno necenzurované a volně asociativní psaní (podobné „volným asociacím" v psychoanalýze). Tomuto psaní předchází podrobné teoretické zdůvodnění otázek a postupu na začátku následného semináŕe. „Nyní během semináře napíší texty ve smyslu, který jsme si vysvětlili (spontánně, asociativně, bez racionální cenzury); ... Doma text přepísí na stroji a bez uvedení jména ho odevzdají... na sekretariátu. Já z odevzdaných textů připravím souborný text, který nám poslouží jako podklad $\mathrm{k}$ diskusi při dalších dvou nebo třech seminárích. Cílem je reflektovat iracionální dynamiku zkušeností v průběhu praktika. Podstatné je, abychom při rozebírání textů nevěděli, kdo je jejich autorem, a nepsychologizovali o účastnících semináře, ale o subjektivních problémových figurách nastíněných $\mathrm{v}$ jednom nebo i více textech." (Würker, s. 63).

Jako vysokoškolský učitel si člověk snadno umí představit, že se „subjektivní 
problémové figury" $\mathrm{v}$ těchto textech a při jejich rozebírání mohou stát průhlednými; že jejich za určitých okolností všeobecnou relevanci lze diskurzivně odkrývat a pomocí procesů identifikace anebo distancování se účastníků na základě jejich významu pro vlastní osobu a vlastní profesní identitu také i přezkoumávat. Mám pocit, že se zde jedná o prríkladný, jasně strukturovaný koncept, který si zasluhuje pozornost. Do jaké míry byl využit i na jiných vysokých školách, zda byl př́padně také dále rozvíjen a zda se dá mluvit i o jeho určitém širším účinku, to vše jsou otázky, jimž by se musela věnovat samostatná studie.

\subsection{Základní osobnostní kom- petence pro učitelské povolání (Univerzita v Kasselu, koncept BASIS)}

$\mathrm{Na}$ Univerzitě v Kasselu vzešel v posledních letech ze spolupráce psychoanalytiků a pedagogů nový přístup ke vzdělávání učitelů. Ten ve své prvotní fázi spojil psychoanalytické a humanisticko-psychologické př́stupy do seminárního konceptu, v jehož středu pozornosti leží prohlubující dialogická sebereflexe studentů i učitelů. Oproti „mainstreamově standardizovaným popisům schopností ve vzdělávání učitelů obhajují autoři nového konceptu nutnost rozvoje „personální sebekompetence“ ve smyslu „osobní kompetence budovat intenzivní, emocionálně naplněné a na důvěře založené vztahy, aby na tomto základě ... posílením svých vlastních zdrojů v daném kontextu byla nabízena aktivní pomoc $\mathrm{v}$ př̌konávání problémů a vyjasňo- vání vlastních cílü“ (Dauber \& Zwiebel, 2006, s. 8). Kasselský koncept je na rozdíl od přístupu $\mathrm{H}$. Brücka určen pro relativně velké seminární skupiny (do 50 účastníků) jako kompaktní seminár pro začínající studenty ke zkoumání profesní motivace a pedagogických kompetencí ve vztahu k druhým osobám.

V BASIS jsou pro studenty definovány tři podstatné cíle:

„Zjišstění a uvědomění si svých vlastních osobnostních kompetencí:

- zjistit a uvědomit si své osobnostní kompetence

- rozpoznat své vlastní silné stránky a vývojový potenciál

Volba povolání/studia:

- reflektovat svou motivaci $\mathrm{k}$ volbě povolání a svůj vlastní obraz učitele

- reflektovat biografické zkušenosti z učení

- přezkoumat správnost volby studia a stupně (př́ípadně také předmětů)

Nastartování vývoje v učení:

- naplánovat př́ítí kroky v učení

- (BASIS, podrobně rozvedené informace $\mathrm{k}$ průběhu semináŕe a vyhodnocování výsledků).

Jak je vzhledem $k$ danému rozsahu pochopitelné, príliš osobního ze strany účastníků - na rozdíl od Brücka - není a nemůže být do seminární práce zahrnuto. „Nicméně jsme vždy hleděli na to, aby se vyloženě osobní a biografické otázky hlouběji nerozebíraly" (tamtéž, s. 113).

Není pochyb, že se zde jedná - pokud ne o protimluv - tak prece jen o omezení vůči stanovování cílů v pedagogické práci se žáky pro personální sebekompetence učitele. Jak je však ze zpráv patrno, v konzultačních 
hodinách i v seminárních zprávách studentů lze tematizovat a probírat i rovinu studentova „životního př́iběhu“.

\subsection{Profilový studijní program poradenství v řešení konfliktů pro pedagogy a pedagožky (Univerzita v Kasselu)}

Podstatně hlubší a podle mne v rámci pregraduálního vzdělávání učitelů doposud ojedinělý koncept představuje Profilový studijni program poradenství v řěseni konfliktu pro pedagogy a pedagožky, rovněž na Univerzitě v Kasselu. Nabízí rozmanité možnosti $\mathrm{v}$ reflektování teorie i praxe a $\mathrm{v}$ supervizi. Jedná se o rozpracovaný studijní program (téměř na „úrovni“ oboru kombinovaného studia), který lze volit jako hlavní studijní zaměření. Studijní jednotku připravuje „oddělení psychoanalýzy“, které za ni také nese odpovědnost. Jako obecný cíl je uváděna rozvinutější odborná kompetence ve třech ohledech:

„Vztah $k$ sobé samému: Bezpodmínečným předpokladem pro zvládání konfliktních situací je prrístup k vlastním niterným, emocionálním konfliktům. Těžištěm tohoto profilového studijního programu je proto podpora sebereflexe.

Vztah k protějsku: Pro chápání vztahů je však rovněž podstatné vnímání druhých a schopnost vcítit se do nich. Proto má být podporována empatie a vnímání druhého (napr. procesy přenosu a protipřenosu), stejně jako schopnost zúčastněného pozorování.

Vztah uvnitr skupiny a ke skupině: Kompetentní zacházení s konflikty ve skupině a se skupinou navíc vyžaduje cit pro skupinovou dynamiku a schopnost intervence; $\mathrm{v}$ tomto profilovém studijním programu by měly být obě zprostředkovány."

K dosažení uvedených cílů má sloužit diferencovaně rozpracovaný studijní program popsaný $\mathrm{v}$ univerzitním materiálu informujícím o studijním oboru (Univerzita v Kasselu, Flyer):

„Psychoanalytická teorie: Poskytuje základy psychoanalytického myšlení a vývojové psychologie, znalosti psychických poruch u dětí a mladistvých, základy vztahové analýzy a psychologie snů. $\mathrm{V}$ tomto rámci existuje možnost definovat vlastní klíčové oblasti.

Sebepoznáváni: Schopnost introspekce je zásadním předpokladem pro kompetentní zacházení s konfliktními situacemi. Prioritou profilového studijního programu je proto podpořit vnímání sebe sama. Možné formy jsou studium textů vztahujících se $\mathrm{k}$ danému obsahu nebo třeba představení ,The Components of Psychic Conflict' či představení $\mathrm{k}$ úvodu do psychodramatu.

Praktické cvičení: V povinném semináři Poradenská praxe mají být cíleně zprostředkovány poradenské kompetence.

Supervize vlastni praktické pedagogické zkušenosti: Supervizní skupina spojuje za účelem reflexe vlastních pedagogických zkušeností účastníky z různých oblastí pedagogické praxe a na různých stupních jejich vzdělání... Účastníkům má poskytnout prostor $\mathrm{k}$ reflektování pedagogického jednání se zaměřením na jeho průvod- 
ní psychodynamické procesy a otevrrít tak nové pohledy na jednání.

Výzkumné projekty: Z konkrétních praktických zkušeností, klíčových studijních úkolů anebo v oblasti psychoanalytické pedagogiky již existujících oblastí výzkumu (např. psychoanalýza raného dětství, teorie vazby, psychoanalýza dospívání, výzkum traumat, didaktika psychoanalýzy) mohou vzniknout drobnější studentské výzkumné projekty, jimž výzkumné kolokvium nabídne doprovodný rámec.

Souvisejici teoretické oblasti: Jako doplněk k psychoanalytické teorii konfliktů se $\mathrm{k}$ prohloubení znalostí doporučuje např. účast na semináŕích z oblasti, společenské konflikty, ,konflikty v rodině, ,konflikty ve škole aj."

Zdá se, že tato z hlediska hlubinné psychologie velice slibná studijní nabídka neměla po roce 2017 dalšího pokračování, nebot jak uvádí univerzitní informační zdroje, nejsou do programu přijímáni noví studenti. Podle dat Univerzity v Kasselu úspěšně zakončilo studium $\mathrm{k}$ srpnu 2017 celkem 222 studentů. Dalších 40 studentů mohlo studium dokončit. Možná se jedná o další z mnoha př́padů, kdy je koncept silně závislý na angažmá jednotlivých osob, jejichž odchod z univerzity znamená ohrožení studijního programu. Současně by se však tento program mohl stát milníkem pro budoucí snahy o zařazení psychodynamických aspektů do vzdělávání učitelů - pakliže se podaři zajistit transparentnost faktorů vývoje, úspěchu a dalších procesních podmínek a dát je $\mathrm{k}$ dispozici širší odborné diskusi.

\section{Diskuse a FACIT - HLEDISKa HLUBINNĚ-PSYCHOLOGICKY ZAMĚ- ŘENÉHO PEDAGOGICKÉHO VÝZKU- MU A VZDĚLÁVÁNÍ UČITELŮ}

Přes několik málo pokusů $\mathrm{v}$ př́pravě učitelů, přes Adornovu naléhavou obhajobu psychoanalytického „vzdělávání a sebereflexe“ z roku 1965 se uvedené snahy nedokázaly prosadit všeobecně. A v dnešní debatě o spojitosti mezi „vzděláváním a emocemi“ (viz Huber, 2018) sehrávají hlubinně-psychologické prrístupy jen okrajovou roli. Príćciny jsou rozmanité a komplexní. Vedle hned na začátku zmiňovaných důvodů zde může mít svůj vliv i obrana, nebot' skutečná reflexe vlastního jáství a osobních sklonů $\mathrm{k}$ přenosu může být bolestným procesem, jemuž vyučující nechtějí vystavovat jen tak snadno ani sebe, ani druhé. V institucionálním kontextu je také nesnadné vytvořit prostor pro nabývání zkušeností a diskurz, který by byl osvobozený od vnějšich tlaků a umožňoval nalézat cestu k „nejhlubšímu“ jáství. Kromě toho pořád není plně vyřešena otázka kvalifikace vysokoškolských učitelů. A tak skupina hlubinně-psychologicky vzdělaných vysokoškolských učitelů pedagogiky prozatím zůstává mimořádně vzácným druhem.

Psychodynamická rovina učitelského povolání - zejména ve vztahu mezi učitelem a žákem - tak stále vyžaduje důkladný výzkum a konceptualizaci, získání dalších zkušeností a diskusi s cílem vymezit specificky pedagogický (a tedy nikoli primárně pedagogicko-terapeutický) a vysokoškol- 
sko-didaktický koncept. Téměř důsledné zaměření hlubinně-psychologicky orientované pedagogiky na oblast nedostatků je samozřejmě zcela pochopitelné. A možná právě v tom leží další překážka pro integraci hlubinně-psychologických přístupů do vzdělávání učitelů. Každá hlubinně-psychologicky orientovaná pedagogika má „uzdravováni" z historického pohledu takřka zapsané $\mathrm{v}$ genech. Toto zaměření je pochopitelné i z pedagogicko-pragmatického hlediska. Citovaná Würkerova kniha o hlubinně-hermeneuticky vyjasněném pohledu na školní „scény“ včetně pedagogického jednání při nich začíná výrazem „rušivé vlivy ve výuce“. Würker tak hned na samém začátku vkládá prst do rány, jež je pro každého učitele, každou učitelku více či méně bolestná. Nebot tam, kde povinnost naráží na přání dělat něco jinak, tam je „rušivý rozpor“ nevyhnutelný; „rušivý rozpor“ v tom smyslu, že se to Jiné nebo ten Jiný začne svým vlastním právem hlásit ke slovu a uplatňovat se „ve hře“. Odzbrojení toho Jiného a tedy eliminace historicky narostlého potenciálu odporu v žákovi pomocí psychoanalytického „školení a sebereflexe“ a nakonec i „změnou v chování " na straně učitele, o čemž Adorno snil (viz výše), se samozřejmě ve skutečnosti nemůže podařit - a vlastně by se podařit ani nemělo. To proto, že ve snaze opanovat nevědomé a vědomé afekty se tomu Odporujícímu (a Kreativnímu) v konečném důsledku podtrhává půda pod nohama a tím také možnost svobody vůbec. Adorno argumentuje na pozadí společensky podmíněné a v hloubi duše číhající represivnosti a jejího zastoupení v osobě autoritárního učitele; tato represivnost má být rozpoznána a zkrocena. Ovšem ve svém vymezení $\mathrm{k}$ terapeutickému př́stupu by se hlubinně-psychologicky založená pedagogika (a vzdělávání učitelů) měla snažit pátrat po takovém pohledu, který v oné „hlubině " nebude prvořadě hledat studnici zla a patogenních tendencí iracionálna, ale hlavně studnici kreativity, naděje, empatie, svobodné hry, poezie, lásky a životní radosti. To by ve smyslu všeobecné základní logiky hlubinně-psychologicky založené pedagogiky znamenalo úkol nového pohledu na pochody „přenosu“, zejména (také) jako psychogeneticky podmíněný a možná i psychohygienicky trvale nutný základ pro navození a udržení emocionálně nosného a individuálně i sociálně plodného vztahu $\mathrm{k}$ druhým lidem a ke světu obecně. Což nemusí vést $\mathrm{k}$ novodobému animismu se všemi jeho fatálními důsledky, jelikož dnes - jinak než v archaických a animismem určovaných, a tím i prostřednictvím „přenosü“ veskrze nesených kulturách - existuje šance, že se ony možné fatální následky nereflektovaného, případně politicky instrumentalizovatelného sklonu $\mathrm{k}$ přenosu u našeho at právem, či neprávem zklamaného současníka podaří rozpoznat. Této možnosti - jako nadějného dědictví osvícenství a kulturně dějinných a psychogenetických procesů, které s ní souvisejí - se můžeme chopit. Biblický „obětní beránek“ a jeho moderní náhražky jsou jistě plodem procesů přenosu a psychického odlehčení; to však nemusí zadávat důvod $\mathrm{k}$ tomu, aby se „mechanismus“ přenosu vůbec patologizoval. 
Pro všechny tyto úkoly by bylo mimořádně užitečné, kdyby se „konflikt škol“ nechal přetransformovat $\mathrm{v}$ konstruktivní dialog, do něhož by se zapojily nejen „staré" hlubinně-psychologické směry, ale i různé př́stupy $\mathrm{z}$ humanistické psychologie (např. Abraham Maslow, Carl R. Rogers, Rollo May, Fritz Perls). Nemá-li se taková snaha zastavit $\mathrm{v}$ diskurzním prostoru sebelásky vzdáleném realitě, pak bude odkázána na intenzivní dialog a kooperaci s množstvím souvisejících disciplín (jako politologie, historie, filozofie, sociologie, př́padně i religionistika a teologie). A podaří-li se přitom obrátit pozornost na tendenci $\mathrm{k}$ přehnané polemice a $\mathrm{k}$ ideologickému „utváření církvi“", která je obsažena už ve „starých“ směrech a v humanistické psychologii je o to zřetelnější, mohla by tato otevřenost podpořit i sebekritický diskurz.

Nicméně již dnes lze na základě předchozích teoretických prací a praktických zkušeností zastávat názor, že psychodynamické aspekty by se do pregraduálního studia pedagogiky začlenit mohly a také měly - jako protiváha funkcionalistických tendencí a tlaků. Jednou možností je připravit trojdílné moduly, jež by se (zpočátku) mohly nabízet jako fakultativní; účel- ně v rámci školního praktika nebo jako doplněk $\mathrm{k}$ němu. $\mathrm{V}$ prvním souhrnném modulu poskytujícím přehled by mohly být vysvětleny historické a systematické základy tématu (přednáška a základní četba), druhý modul by nabízel specifické prohloubení tématu (formou semináře) a ve třetím modulu by probíhal teoreticko-praktický semináŕ v malých skupinách. Poslední ze zmíněných by měl zahrnovat průzkum v „terénu“ (např. smysluplně nadimenzovaná výzkumná praktika) a zejména pak nabídku k sebepoznávání a sebereflexi v důvěrném studijním prostředí, maximálně oproštěném od tlaku na výkon.

Jinými slovy, je třeba dál pátrat po možnostech, jak zařadit psychoanalytické znalosti - anebo vůbec: hlubinně-psychologická hlediska a hlubinně-hermeneutické postupy - do vzdělávání vychovatelů a učitelů obecně. Je to způsob, jak otevř́ít cestu k poznání, že ten druhý je opravdu jiný než já. Souběžně s tím je možno rozvíjet cit pro význam přenosů a tím i cit pro přenosy zatěžujícího nebo patogenního druhu v sociálních situacích. Nechceme-li ze svého protějšku učinit obět našich vlastních nevědomých přenosů, pak má to posledně zmíněné důležitou roli.

\section{LITERATURA}

Adorno, T. W. (1965). Tabus über dem Lehrerberuf [Tabu učitelského povolání]. (Online). Dostupné z www2.ibw.uni-heidelberg.de/-gerstner/TabusText.pdf

Ballauff, T. (1969). Pädagogik: Eine Geschichte der Bildung und Erziehung [Pedagogika: Déjiny vzdělávání]. Sv. 1. Freiburg: Karl Alber.

Brück, H. (1978). Die Angst des Lehrers vor seinem Schüler. Zur Problematik verbliebener Kindlichkeit in der Unterrichtsarbeit des Lehrers - ein Modell [Strach učitele ze svého žáka. K problematice zbývajici dètskosti ve výukové práci učitele - model]. Reinbek bei Hamburg: Rowohlt. 
Datler, M. (2012). Die Macht der Emotion im Unterricht. Eine psychoanalytisch-pädagogische Studie [Sila emocí ve výuce. Psychoanalyticko-pedagogická studie]. Gießen: Psychosozial Verlag.

Dauber, H., \& Zwiebel, R. (2006). Professionelle Selbstreflexion aus pädagogischer und psychoanalytischer Sicht [Profesionálni sebereflexe z pedagogického a psychoanalytického hlediska]. Bad Heilbrunn: Klinkhardt.

Erasmus Rotterdamský (1960). Das Lob der Torheit [Chvála bláznivosti]. Basel und Stuttgart: Birkhäuser. (1. vyd. 1511).

Gitz-Johansen, T. (2016). Jung in education [Jung ve vzdělávání]. Journal of Analytical Psychology, 61(3), 365-384.

Herrmann, U. (Ed.). (2012). Reformpädagogik: Eine kritisch-konstruktive Vergegenwärtigung [Reformni vzdéláváni: Kriticky konstruktivni vizualizace]. Bad Heilbrunn: Klinkhardt.

Huber, M. et al. (Ed.). (2018). Bildung und Emotion [Vzdèláni a emoce]. Wiesbaden: Springer. Jung, C. G. (1926). Analytische Psychologie und Erziehung [Analytická psychologie a vzdělávání]. Heidelberg: Kampmann.

Mayes, C. (2017). Teaching and learning for wholenesss [Vyuka a učeni pro celistvost]. Lanham: Rowman.

Reimer, G (2006). Unbewusste Beziehungsformen zwischen Lehrern und Schülern [Nevédomé vztahové formy mezi učiteli a žáky]. Dizertační práce. Univerzita Duisburg-Essen. (Online).

Rüedi, J. (1995). Individualpsychologische Lehrerinnen- und Lehrerbildung - ein Erfahrungsbericht [Individuálně psychologická př́íprava učitelek a učitelů - zpráva z terénu]. Zeitschrift für Individualpsychologie, 20, 23-31.

Semetsky, I. (Ed.). (2013). Jung and educational theory [Jung a vzdělávací teorie]. Chichester, UK: Wiley.

Skiera, E. (2010). Reformpädagogik in Geschichte und Gegenwart. Eine kritische Einführung [Reformni vzdéláváni v historii a soućasnosti. Kritický úvod]. München: Oldenbourg.

Skiera, E. (2011). Reflexive Selbsterfahrung als Weg zur Seele. Übungen zur Vertiefung der Beziehung zu sich selbst, zum Anderen und zur Natur [Reflexni sebevédomí jako cesta $k$ duši. Cvičeni $k$ prohloubeni vztahu se sebou samým, ostatnimi a prírodou]. Bad Heilbrunn: Klinkhardt.

Spiel, O. (1947/1979). Am Schaltbrett der Erziehung [Na desce vzdělání]. Bern u.a.O.: Hans Huber.

Univerzita v Kasselu (2016). Kurzfassung Projekt BASIS „Personale Basiskompetenzen für den Lehrerberuf" [Krátká verze projektu „Osobni základni dovednosti pro učitelskou profesi"]. (Poskytl spoluautor H. Dauber).

Univerzita v Kasselu (2018). Flyer „Konfliktberatung für Pädagoginnen“ [„Konfliktní konzultace pro pedagogy"]. Dostupné z www.uni-kassel.de 
Wisniewski, B. (2016). Psychologie für die Lehrerbildung [Psychologie pro vzdèláváni učiteliu]. Bad Heilbrunn: Klinkhardt.

Würker, A. (2007). Lehrerbildung als Szenisches Verstehen. Professionalisierung durch psychoanalytisch orientierte Selbstreflexion [Vzdèláváni učiteliu jako scénické chápáni. Profesionalizace pomoci psychoanalyticky orientované sebereflexe]. Hohengehren: Schneider.

Prof. Dr. Ehrenhard Skiera

emeritni profesor, Univerzita Flensburk; e-mail: skiera@uni-flensburg.de

Překlad Mgr. Eva Magdalena Šulcová.

SKIERA, E. On the Emotional Depth Dimension of Pedagogical Situations in Schools: The search for clues on how to integrate depth psychology orientated self-experience in teacher education

Although almost every educator knows that the pedagogical space is filled with profound emotions that shape the interactions, it has so far hardly been possible to give the associated questions an appropriate place in teacher education. Nevertheless, there are approaches that attempt to integrate depth psychological aspects into the "normal" teacher education for pre-school, primary and secondary education. Of decisive importance here are those concepts that go beyond theory-based information or teaching and the study of relevant texts in lectures and seminars, and integrate elements of self-reflection and "reflexive self-awareness" curricularly and institutionally. Only by a lively connection of personal experience and reflection can deep psychological knowledge be acquired critically and constructively as well as become practically effective. With regard to the development of concepts for the teaching profession, it would be extremely helpful if the well-known "quarrel of the schools" could be transformed into a creative dialogue, including not only the different psychoanalytical perspectives but also the different approaches within the field of humanistic psychology.

Keywords: teacher education, depth psychology, psychoanalysis, analytical psychology, individual psychology, humanistic psychology. 